\title{
Sexual dimorphism in Amphisbaena nigricauda (Reptilia, Squamata, Amphisbaenidae) from Southeastern Brazil
}

\author{
Francco A. N. de Souza e Lima', João Luiz Gasparini ${ }^{2}$, Antonio de Padua Almeida ${ }^{3}$, \\ Marcos V. C. Vital ${ }^{4}$ \& Tamí Mott ${ }^{4}$
}

1. Instituto de Biociências, Universidade Federal de Mato Grosso, 78060-900, Cuiabá, MT, Brazil.

2. Departamento de Ecologia e Oceanografia, Universidade Federal do Espírito Santo, 29060-900 Vitória, ES, Brazil.

3. Instituto Chico Mendes de Conservação da Biodiversidade - Reserva Biológica de Comboios, 29900-970, Linhares, ES, Brazil

4. Instituto de Ciências Biológicas e da Saúde, Universidade Federal de Alagoas, 57072-970 Maceió, AL, Brazil. (tamimott@hotmail.com)

\begin{abstract}
Amphisbaena nigricauda Gans, 1966 is a small, poorly known amphisbaenid endemic to the restinga of the states of Espírito Santo and Bahia, Brazil. We analyze 178 specimens collected in Vitória municipality, state of Espírito Santo, Brazil, to investigate whether this species show sexual dimorphism in pre-cloacal pores and in morphological characters. Sex was determined by a ventral incision and direct inspection of gonads. A PCA analysis was performed to generate a general body size measurement. A T test and the non-parametric Mann-Whitney test were used to assess whether this species show sexual dimorphism on five morphometric and five meristic characters, respectively. Sex could not be determined in 36 specimens because they were mutilated in the posterior portion of their bodies. The diagnosis of the species is redefined based on this sample size: the smallest number of body annuli changes from 222 to 192, the number of dorsal and ventral segments in an annulus in the middle of the body changes to 9-11/13-16 (instead of 10/16), and the autotomic tail annulus lies between annulus 7-10 (instead of 6-9). The number of tail annuli remained within the known range of variation of the species (19-24). None of the 80 females analyzed showed pre-cloacal pores, whereas within males 59 out of 62 specimens displayed four and two specimens displayed five pre-cloacal pores. A single male did not possess pre-cloacal pores, but showed irregular scales on its cloacal region. Sex-based difference based on presence or absence of pre-cloacal pores as well as males with wider head was seen in other Neotropical amphisbaenids. However, a pattern of body size differences between males and females has not been identified so far in the few amphisbaenid species studied in this regard. Further studies on this taxonomic group are still needed to elucidate the existence of general patterns of sexual dimorphism and to identify the selective pressures driving these patterns.
\end{abstract}

KEYWORDS. Amphisbaenia, Espírito Santo, restinga, sexual dimorphism.

RESUMO. Dimorfismo sexual em Amphisbaena nigricauda (Reptilia, Squamata, Amphisbaenidae) do Sudeste do Brasil. Amphisbaena nigricauda Gans, 1966 é uma pequena anfisbênia pouco conhecida endêmica da restinga dos estados do Espírito Santo e Bahia, Brasil. Analisamos 178 indivíduos coletados no município de Vitória, Espírito Santo, Brasil, para verificar se esta espécie apresenta dimorfismo sexual nos poros précloacais e em caracteres morfológicos. O sexo foi determinado por uma incisão ventral e inspeção direta das gônadas. Uma análise de PCA foi realizada para gerar uma medida geral do tamanho do corpo. O test-T e o teste de Mann-Whitney não paramétrico foram utilizados para avaliar se esta espécie apresenta dimorfismo sexual em cinco caracteres morfométricos e cinco merísticos, respectivamente. O sexo não pode ser determinado em 36 indivíduos porque eles estavam mutilados na parte posterior do corpo. O diagnóstico da espécie é redefinido com base nesta amostra: o menor número de anéis corporais alterou de 222 para 192, o número de segmentos dorsal e ventral em um anel no meio do corpo mudou de 9-11/13-16 (ao invés de 10/16), e o anel autotômico na cauda encontra-se entre 7-10 (ao invés de 6-9). O número de anéis caudais permaneceu dentro do intervalo de variação conhecida para a espécie (19-24). Nenhuma das 80 fêmeas analisadas apresentou poros pré-cloacais, enquanto que, dentro os 62 machos, 59 apresentaram quatro e dois indivíduos cinco poros pré-cloacais. Um único macho não tinha poros pré-cloacais, mas apresentava escamas irregulares em sua região cloacal. Diferença sexual quanto à presença ou ausência de poros pré-cloacais, assim como machos apresentando cabeças mais largas que a fêmeas, foi observada em outros anfisbenídeos neotropicais. No entanto, um padrão de diferenças de tamanho corporal entre machos e fêmeas não tinha sido identificado até agora nas poucas espécies de anfisbênias estudadas. Outros estudos com este grupo taxonômico ainda são necessários para elucidar a existência de padrões gerais de dimorfismo sexual e identificar as pressões seletivas que resultam estes padrões.

PALAVRAS-CHAVE. Anfisbênias, Espírito Santo, restinga, dimorfismo.

Amphisbaenia is a monophyletic group (TownSEND et al., 2004) of fossorial reptiles (Squamata) represented by 184 taxa (UeTz, 2014). Among the six families (VIDAL et al., 2008), the Amphisbaenidae include the majority $(\mathrm{n}=169,91.8 \%)$ of amphisbaenian species (Uetz, 2014) distributed mainly in Africa, Central and South America (Strüssmann \& Motт, 2009). Brazil harbors the highest diversity of amphisbaenians worldwide (MоTT \& VIEITES, 2009 ) with 69 species currently catalogued in the country (BÉrNiLs \& Costa, 2012; Roberto et al., 2014).

Due to amphisbaenians' fossorial habits, collecting specimens is frequently difficult. Consequently, the descriptions of many species are based on a limited number of specimens and almost all aspects of their basic biology and ecology are poorly known (VEGA, 2001; NAVEGAGonÇALVES, 2009). The typically small number of known specimens also limits knowledge of morphological variation in many species, including sex-based differences.

The morphometric studies of amphisbaenids that have been performed indicate that sexual dimorphism may be common. WeBB et al. (2000) compared total length and head width of two African species Monopeltis anchietae (Bocage, 1873) and Zygaspis quadrifrons (Peters, 1862) (Amphisbaenidae), observing that females of Monopeltis have wider head than males and females of Zygaspis have larger body than males. Conversely, GiL et al. (1993) and MÁrtin et al. (2012) observed that males of Blanus cinereus (Vandelli, 1797) (Blanidae) and Trogonophis 
wiegmanni Kaup, 1830 (Trogonophiidae) respectively have wider head than females. For Bipes biporus (Cope, 1894) (Bipedidae), head shape does not differ between sexes (Kearney, 2003). For Neotropical amphisbaenids, sex-based morphological differences were investigated for Amphisbaena alba Linnaeus, 1758 (ColLI \& ZAMBONI, 1999); Amphisbaena kingii (Bell, 1833) and Amphisbaena munoai Klappenbach, 1960 (BALESTRIN \& CAPPELLARI, 2011); Amphisbaena ibijara Rodrigues, Andrade \& Lima, 2003 and Leposternon polystegum (Duméril, 1851) (GoMEs et al., 2009); Leposternon wuchereri (Peters, 1879) and Leposternon microcephalum Wagler, 1824 (Filogonio et al., 2009); and Amphisbaena prunicolor (Cope, 1885) (MACIEL et al., 2012). These studies generally found that females are larger than males (exception to Leposternon microcephalum whereas total length do not differ, and L. polystegum whereas males are larger than females), following the same pattern found in other squamate reptiles (SHINE, 1994). Another sexual dimorphism detected in amphisbaenids is related to the presence/absence of pre-cloacal pores: in contrast to males some female amphisbaenids such as Amphisbaena kingii (VEGA, 2001), A. dubia L. Müller, 1924, A. heathi Schmidt, 1936 (VAnzolini, 2002), A. uroxena Mott, Rodrigues, Freitas \& Silva, 2008 and $A$. anaemariae Vanzolini, 1997 (Мотт et al., 2011) do not show pores.

Amphisbaena nigricauda Gans, 1966 is a small and slender amphisbaenid (maximum Snout Vent Length $=105$ $\mathrm{mm}$ ) endemic to the states of Espírito Santo and Bahia, Brazil (Dias \& Rocha, 2005; Silva-Soares et al., 2011). The type series consists of three specimens (a female, a juvenile and a male) collected in 1964 at Sooretama Refuge (now the Reserva Biológica de Sooretama - Fig. 1 ) in the municipality of Linhares ( $\left(9^{\circ} 00^{\prime} \mathrm{S}, 40^{\circ} 08^{\prime} \mathrm{W}\right)$, state of Espírito Santo, Brazil. A large series of this species was obtained in the municipality of Vitória, Espírito Santo State by one of the authors (JLG) - one of the specimens from this series was used to extend the species known distribution ca. $135 \mathrm{~km}$ southeast (SiLVA-SoAres et al., 2011). Here, we use this series of 178 specimens to analyze variation in morphological characters and to assess sexbased differences in this poorly known species.

\section{MATERIAL AND METHODS}

All specimens of Amphisbaena nigricauda were collected from July 2005 to November 2006 when vegetation was suppressed by bulldozers during expansion of airport facilities in the restinga (coastal sand-dune vegetation) of Praia de Camburi (20¹6'16”'S, 40¹6’35”'W), Vitória, Espírito Santo, Brazil (Fig. 1). Vitória municipality comprises a main area located on an island within a bay, and a northern portion located on the mainland, where Camburi is located. The climate is Aw Tropical (KöPPEN, 1936) with an annual mean temperature of $23^{\circ} \mathrm{C}$ and precipitation of

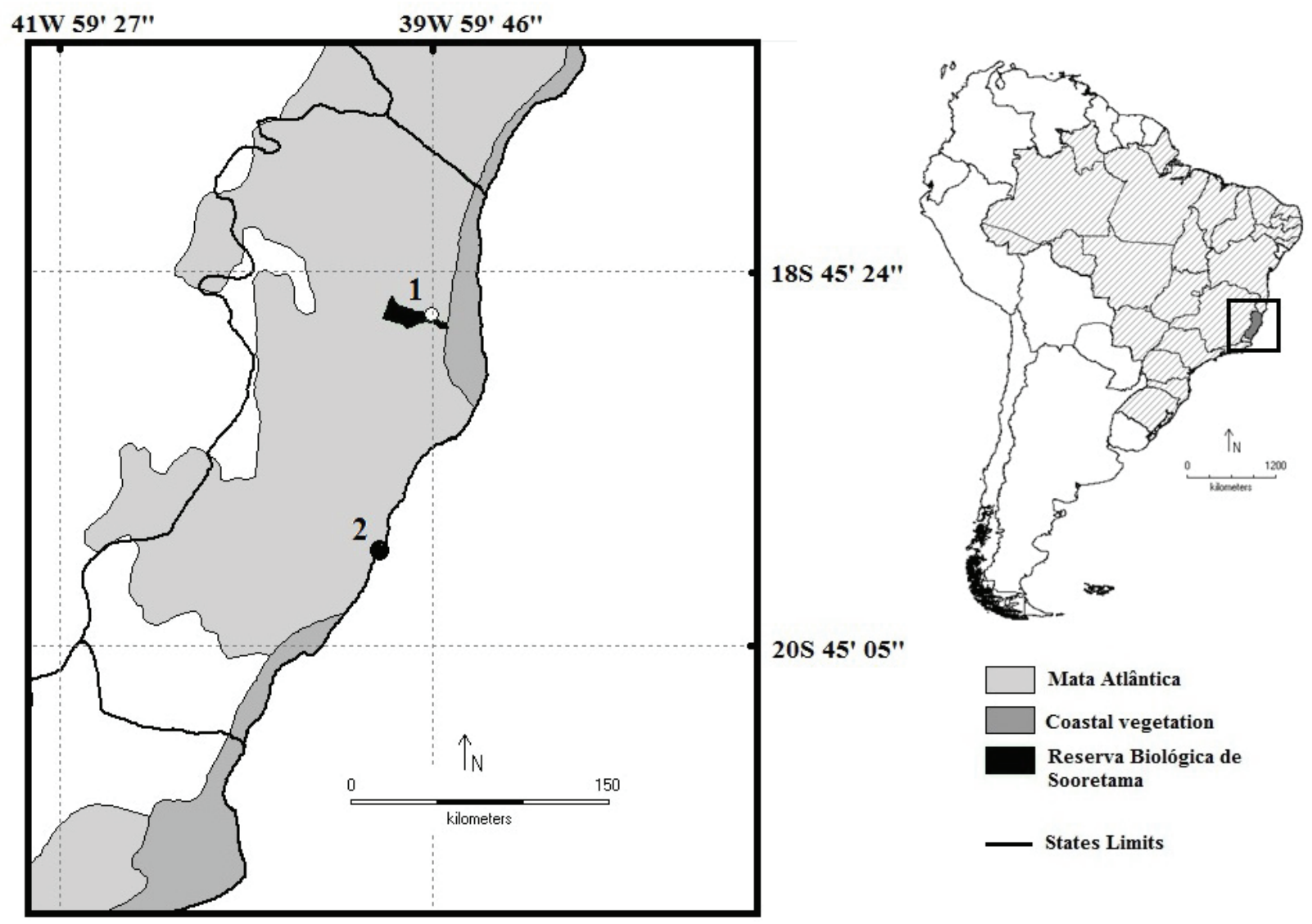

Fig. 1. Geographic distribution of Amphisbaena nigricauda Gans, 1966: 1, type locality, Linhares municipality; 2, Vitória municipality. Both records are located in the state of Espírito Santo, Brazil. Squared polygon in the South American inset map highlights the state of Espírito Santo, Brazil. 
around 1,230 mm (Silva-SoARes et al., 2011).

Specimens obtained were kept under observation for one hour; individuals in apparently healthy conditions were released, and those damaged were euthanized with xylocaine, fixed in 5\% formalin, and transferred to $70 \%$ alcohol. Specimens are housed either at Coleção Zoológica de Vertebrados da Universidade Federal de Mato Grosso, campus Cuiabá (CZV-UFMT), Cuiabá, state of Mato Grosso, Brazil, and Museu de Biologia Professor MelloLeitão (MBML), Santa Teresa, state of Espírito Santo, Brazil (Appendix). Collection permits were granted by the Instituto Brasileiro do Meio Ambiente e dos Recursos Naturais Renováveis - IBAMA/ES: NUFAUNA no. 38/06 and 10/05, processes 2281/05-22 and 3471/06.

Counts of body annuli were made along the left side of the ventral surface following GANS \& ALEXANDER (1962). The following meristic data taken for each specimen: body annuli (BA), intercalated annuli (IA), annuli interrupted by the cloacal region (AIC), tail annuli (TA), autotomic annuli (AA), dorsal/ventral segments in an annulus at midbody (D/V), and number of pre-cloacal pores (PP). Morphometric data were taken using a metric tape or a digital paquimeter (accuracy of $0.01 \mathrm{~mm}$ ) and consisted of snout-vent length (SVL), tail length (TL), head width (HW), head height (HH), and total length (LT).

Sex was determined by gonad inspection through a ventral incision of ca. $5 \mathrm{~cm}$. Although precise data on collecting was not available, we determined the reproductive stage (mature or immature) of each specimen, the position of testes and the number of eggs or follicles. Males with convoluted vas deferens and females with either ovarian follicle larger than one millimeter or oviduct eggs were considered reproductive, all other individuals were considered non-reproductive. All data were taken by one of the authors (FANSL) using a stereomicroscope.

The presence or absence of pre-cloacal pores was analyzed in all non-mutilated specimens. Within this sample, differences between sexes were analyzed by two statistical approaches including only specimens with intact tails. The continuous morphometric data was analyzed by $\mathrm{T}$ tests, whereas the discrete meristic data were analyzed by non-parametric Mann-Whitney tests. Since the morphometric variables were expected to be highly correlated, they were first subject of a Principal Component Analysis (PCA), and further tests were performed with the most informative PCA axes rather than raw data. In order to account for the possible correlation between meristic data, the non-parametric Spearman correlation was calculated between tail annuli, dorsal and ventral segments in an annulus, the number of annuli interrupted by the cloacal region and the number of body annuli. All data analysis was performed using $R$ environment (R CORE TEAM, 2013).

\section{RESULTS}

A total of 178 specimens of Amphisbaena nigricauda were analyzed, 36 of which were excluded because they were mutilated. Based on these specimens the morphological diagnosis of $A$. nigricauda is redefined: the smallest number of body annuli changes from 222 to 192 , the number of dorsal and ventral segments in an annulus in the middle of the body changes from 10/16 to 9-11/13-16, and the autotomic tail annulus lies between annulus 7 and 10 instead of 6-9. The number of tail annuli (19-22) remained within the range of the known variation (19-24) of the species. The largest specimen known for the species becomes a male of $168 \mathrm{~mm}$ (MBML 3092) where previously it was $105 \mathrm{~mm}$ (paratype AMNH 97205). Specimens larger than $134 \mathrm{~mm}$ in total lengths showed darker brown coloration in the posterior part of their bodies than smaller ones, which have a more uniform brown color.

Eighty females and 62 males (Appendix) of $A$. nigricauda were sufficiently intact for evaluation of presence/absence of pre-cloacal pores. However, only 23 females and 19 males had intact tails and the dimorphism sexual analyses included only these specimens. Males possessed four $(\mathrm{n}=59)$ or five $(\mathrm{n}=2)$ rounded pre-cloacal pores (Figs 2, 3) - there was one exception (MBML 3082),
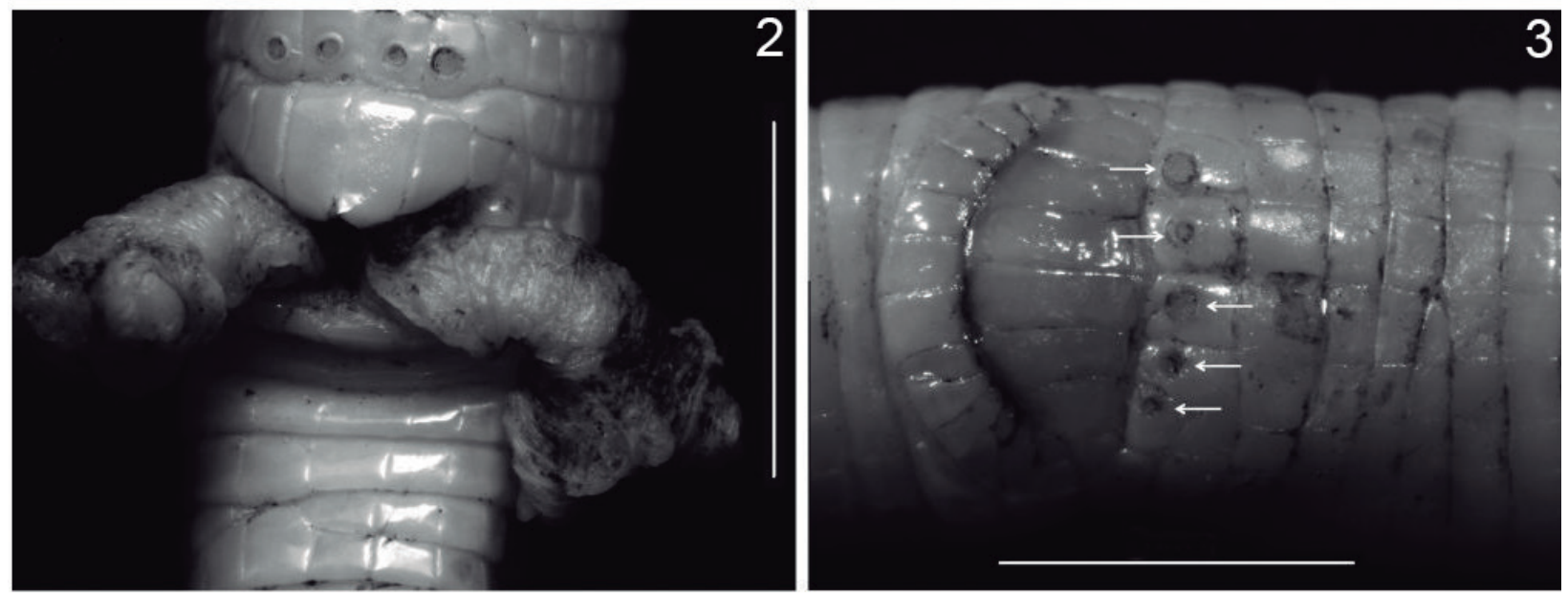

Figs 2, 3. Cloacal region of males of Amphisbaena nigricauda Gans, 1966 from Vitória municipality, state of Espírito Santo, Brazil: 2, MBML 3131 with four round pre-cloacal pores and an everted hemipenes; 3, MBML 3096 with five pre-cloacal pores (white arrows). Bars: $3 \mathrm{~mm}$. 
where pores were absent in irregular pre-cloacal scales. Pores were absent in all females, although in one female specimen (MBML 3119) pale scars of pores could be seen in the pre-cloacal region.

The first axis of the PCA performed with the morphometric data accounted alone for $79.4 \%$ of data variability, and all variable loadings (i.e., the correlation between variables and the axis) were at least 0.84 and were positively correlated with the axis. Thus, this first axis was considered as a general measure of body size and further used in a Welch $\mathrm{T}$ test for heterogeneous variances (homogeneity of variances was rejected by a Levene test) to verify if there is a sexual body size dimorphism in this species. Males were found to have larger values at the first PCA axis than females $(\mathrm{t}=3.04, \mathrm{df}=34.95$ and $\mathrm{p}=0.004)$, as can be seen in Fig. 4, indicating that males are generally larger. The average total body size difference between sexes was $104.7 \mathrm{~mm}$, with males being $7.5 \%$ larger than females. Males also have wider heads than females: on average, males head width was $10 \%$ larger than females $(2.5 \mathrm{~mm})$. The average measurements and differences between sexes are shown in Tab. I.

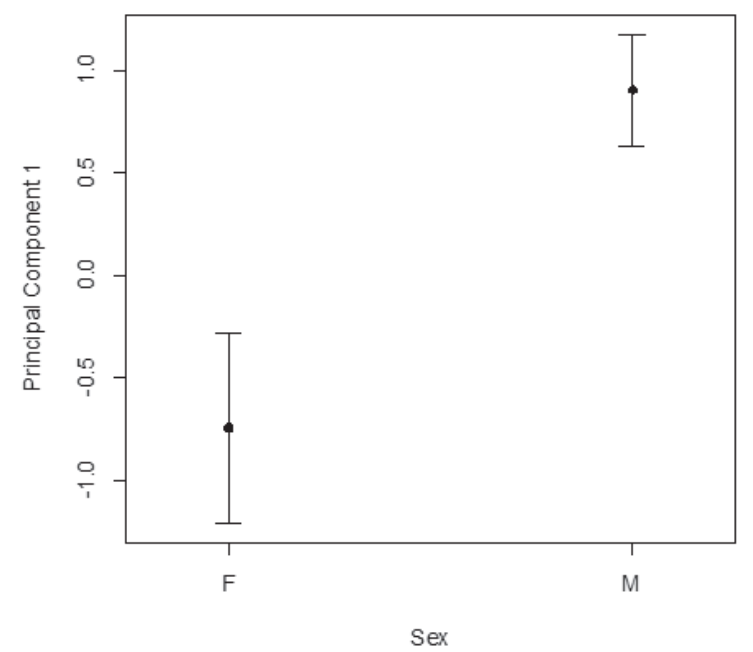

Fig. 4. Average (dots) and standard errors of the first axis of a PCA considering all five morphometric variables of Amphisbaena nigricauda Gans, 1966. The axis accounts for $79.4 \%$ of data variability and positively represents all morphometric measurements. Males are statistically larger than females when compared by a Welch $\mathrm{T}$ test $(\mathrm{t}=3.04, \mathrm{df}=34.95$ and $\mathrm{p}=0.004)$.

Tab. I. Average morphometric measurements (in $\mathrm{mm}$ ) and average differences (raw and percentage differences) from males and females of Amphisbaena nigricauda Gans, 1966 (SVL, snout-vent length; TL, tail length, HW, head width; HH, head height; LT, total length).

\begin{tabular}{lcccc}
\hline & & \multicolumn{2}{c}{ Average difference } \\
\cline { 3 - 5 } & Males & Females & $\begin{array}{c}\text { Raw } \\
\text { differences }\end{array}$ & $\begin{array}{c}\text { Percentage } \\
\text { difference }\end{array}$ \\
\hline SVL & 131.58 & 123.04 & 8.54 & 6.94 \\
TL & 16.26 & 14.13 & 2.13 & 15.09 \\
HW & 2.73 & 2.48 & 0.25 & 10.05 \\
HH & 2.36 & 2.22 & 0.14 & 6.39 \\
LT & 148.74 & 138.26 & 10.48 & 7.58 \\
\hline
\end{tabular}

In contrast, meristic variables were not highly correlated, as can be seen by the Spearman correlations (Tab. II). Differences between sexes within those variables were then analyzed one by one, but no statistically significant results were found by the Mann-Whitney tests performed: AIC, annuli interrupted by the cloacal region $(\mathrm{W}=248.5, \mathrm{p}=0.36), \mathrm{TA}$, tail annuli $(\mathrm{W}=216, \mathrm{p}=0.95), \mathrm{D}$, dorsal segments in an annulus at midbody $(\mathrm{W}=201, \mathrm{p}=0.39)$, $\mathrm{V}$, ventral segments in an annulus at midbody ( $\mathrm{W}=255.5$, $\mathrm{p}=0.85)$ and $\mathrm{BA}$, body annuli $(\mathrm{W}=189, \mathrm{p}=0.46)$.

Tab. II. Spearman rank correlation between the meristic data of Amphisbaena nigricauda Gans, 1966 (AIC, annuli interrupted by the cloacal region; TA, tail annuli; $\mathrm{D} / \mathrm{V}$, dorsal/ventral segments in an annulus at midbody; BA, body annuli).

\begin{tabular}{cccccc}
\hline & AIC & TA & V & D & BA \\
\hline AIC & 1 & & & & \\
TA & -0.046 & 1 & & & \\
V & 0.002 & 0.108 & 1 & & \\
D & -0.051 & -0.136 & 0.376 & 1 & \\
BA & 0.133 & -0.024 & 0.081 & -0.202 & 1 \\
\hline
\end{tabular}

Of the 80 females without evident pre-cloacal pores, $26(32.5 \%)$ had vitellogenic follicles (either primary or secondary), 12 had one or two eggs (15\%) and 42 (52.5\%) did not have any follicle or egg and were considered not reproductive. Among males, $44(70.9 \%)$ had the right testicle more cranial than the left testicle, two $(3.2 \%)$ had left testicles more cranial, and in five of them $(8.0 \%)$ the testes were symmetrical in position. Thirty-six males (58\%) had convoluted vas deferens and 26 (42\%) had not.

\section{DISCUSSION}

Gans (1966) defined the diagnostic characters of Amphisbaena nigricauda based on the three available specimens as: body annuli 222-226; tail annuli 19-24; autotomic tail annulus 6-9 darker than remaining tail annuli; dorsal/ventral segments at midbody $10 / 16$; intercalated annuli absent; brownish coloration with dorsum slightly darker than ventral region. Our analysis of an additional 178 specimens of $A$. nigricauda provides a more accurate identification of diagnostic characters, expands the known morphological range and indicates sex-based differences in body size. Moreover, although Gans (1966) does not mention the presence of intercalated annuli, these are frequently found in the species - 112 specimens $(62.9 \%)$ had intercalated annuli.

Gans (1966) analysis of three specimens of both sexes found four and five rounded pre-cloacal pores. Only two male specimens in our analysis displayed five pores and none of the 80 analyzed females had pores.

Sexual dimorphism in body size has been observed in a few amphisbaenian species, although no clear trend has emerged: females can be larger than males, sexes can have similar sizes or males can be larger than females (as we observed for A. nigricauda). Given the scarcity of data, 
the causes of this variability are uncertain. Larger females may reflect increased fecundity while larger males may be a consequence of male-male competition (combat bouts) for access to females. Similar sizes may reflect constraints imposed by a fossorial lifestyle and more research is still needed to clarify this.

As with body size, there is considerable inter-species variation in sexual dimorphism in head width. Males can have wider head [as seen in Blanus cinereus (GIL et al., 1993), Leposternon microcephalum and L. wuchereri (FIlogonio et al., 2009), Trogonophis wiegmanni (MÁrTIN et al., 2012), and A. nigricauda (this study)], narrower head [Monopeltis anchietae (WEBB et al., 2000)] or even similar head width [Amphisbaena alba (COLLI \& ZAMBONI, 1999), Zygaspis quadrifrons (WEBB et al., 2000), Bipes biporus (KeARney, 2003), Amphisbaena ibijara and Leposternon polystegum (Gomes et al., 2009)]. However, once again, the selective pressures driving these differences are poorly understood. Amphisbaenians are head-first burrowers (GANs, 1969) and head width may be associated either with digging capabilities (speed of burrowing) or with intersexual niche divergence (a larger head may allow the capture of larger prey) or even sexual interactions (male-male combat). There is some evidence that Blanus cinereus individuals (a round-headed species) with longer and narrower heads are able to burrow faster (López et al., 1997). NAVAs et al. (2004) suggested that the amount of force produced during digging in a shovel-headed amphisbaenian species, Leposternon microcephalum, is positively correlated with head width and body length. However, Colli \& ZAMBONI (1999) found no association between prey size and head width in Amphisbaena alba and BALESTRIN \& CAPPELLARI (2011) found no intersexual differences in volume and diet consumption of Amphisbaena kingii and Amphisbaena munoai - although the authors did not measure head widths. As reproductive behavior has been rarely observed in amphisbaenians, little can be said regarding the role of male-male competition driving sexual dimorphism.

Navega-Gonçalves (2009) studied the internal anatomy of six Neotropical amphisbaenids and found that right testicle is more cranial than the left in Amphisbaena vermicularis, A. kingii, A anomala, A. bedai, A. cuiabana and Leposternon microcephalum. Mотт et al. (2011) found the same pattern in Amphisbaena uroxena. In the present study we found a higher prevalence of males with the right testicle more cranial than the left. The asymmetrical disposition of elongated paired testes (generally moved forwards) may be because to the need to accommodate the gonads in the elongated body of amphisbaenians (NAVEGAGonÇALVES, 2009). Further studies on sexual dimorphism on Amphisbaenia are still needed to elucidate if there are general patterns and to identify the selective pressures driving these patterns.

Acknowledgements. Authors thank M. A. Carvalho (UFMT) and H. Q. B. Fernandes (MBML) for access to the specimens under their care; J. L. G. thank J. A. Passamani, T. D. de Novaes and V. S. Queiroz (NUFAUNA-IBAMA/ES) for permits; CEPEMAR and INFRAERO for logistical support; J. A. Pinto, E. Ferreira, B. B. Loureiro and R. Rodrigues provided field assistance and J. P. da Silva for their help in catalogued the specimens; FANSL and TM thank NIEFA - Núcleo Interdisciplinar de Estudos Faunísticos (FAPEMAT process 447441/2009), and A. C. Ribeiro for photos. Thanks to R. J. Ladle for proof-reading the manuscript.

\section{REFERENCES}

Balestrin, R. L. \& CAppellari, L. H. 2011. Reproduction and feeding ecology of Amphisbaena munoai and Anops kingi (Amphisbaenia, Amphisbaenidae) in the Escudo Sul-Rio-Grandense, southern Brazil. Iheringia, Série Zoologia 101(1-2):93-102.

Bérnils, R. S. \& CostA, H. C. orgs. 2012. Brazilian reptiles - List of species. Available at $<$ http://www.sbherpetologia.org.br/>. Accessed on 12 October 2013.

Colli, G. R. \& Zamboni, D. S. 1999. Ecology of the worm-lizard Amphisbaena alba in the Cerrado of central Brazil. Copeia 3:733-742.

Dias, E. J. R. \& Rосна, C. F. D. 2005. Os répteis nas restingas do estado da Bahia: Pesquisa e ações para a sua conservação. Rio de Janeiro, Instituto Biomas. 36p.

Filogonio, R.; Galdino, C. A. B.; Cabral, D. P. R.; Righi, A. F.; Lopes, M. F. \& Nascimento, L. B. 2009. Sexual dimorphism in Leposternon microcephalum and L. wuchereri (Squamata: Amphisbaenidae) from Minas Gerais, Southeastern Brazil. Herpetologica 65:353-362.

Gans, C. 1966. Studies on amphisbaenids (Amphisbaenia, Reptilia). 3. The small species from southern South America commonly identified as Amphisbaena darwini. Bulletin of the American Museum of Natural History 134:185-260.

1969. Amphisbaenians - reptiles specialized for a burrowing existence. Endeavour 28:146-151.

Gans, C. \& Alexander, A. A. 1962. Studies on amphisbaenids (Amphisbaenia, Reptilia). 2. On the amphisbaenids of the Antilles. Bulletin of the Museum of Comparative Zoology 128:65-158.

Gil, M. J.; Guerrero, F. \& Pérez-Mellado, V. 1993. Observations on morphometrics and ecology in Blanus cinereus (Reptilia: Amphisbaenia). Journal of Herpetology 27:205-209.

Gomes, J. O.; Maciel, A. O.; Costa, C. L. \& Andrade, G. V. 2009. Diet Composition in Two Sympatric Amphisbaenian Species (Amphisbaena ibijara and Leposternon polystegum) from the Brazilian Cerrado. Journal of Herpetology 43:377-384.

KeARney, M. 2003. Diet in the Amphisbaenian Bipes biporus. Journal of Herpetology 37:404-408.

KöPPEN, W. 1936. Das geographische System der Klimate. In: KöPPEN, W. \& GeIGER, R. eds. Handbuch der Klimatologie. Berlin, Gebrüder Bornträger, v.5. p.1-44.

López, P.; Mártin, J. \& Barbosa, A. 1997. State and morphological dependent escape decisions in a fossorial lizard. Journal of Morphology 232:289.

Maciel, R. P.; Ribeiro, S. \& Borges-Martins, M. 2012. Reappraisal of the taxonomic status of Amphisbaena prunicolor (Cope 1885) and Amphisbaena albocingulata Boettger 1885 (Amphisbaenia: Amphisbaenidae). Zootaxa 3550:1-25.

Mártin, J.; Polo-Cavia, N.; Gonzalo, A.; López, P. \& Civantos, E. 2012. Sexual Dimorphism in the North African Amphisbaenian Trogonophis wiegmanni. Journal of Herpetology 46:338-341.

Motт, T. \& Vieites, D. R. 2009. Molecular phylogenetics reveals extreme morphological homoplasy in Brazilian worm lizards challenging current taxonomy. Molecular Phylogenetics and Evolution 51:190200.

Mott, T.; Rodrigues, M. T. \& Freitas, M. A. 2011. Amphisbaena uroxena Mott, Rodrigues, De Freitas and Silva 2008 (Squamata, Amphisbaenidae) shows sexual dimorphism in precloacal pores. Zootaxa 3043:33-34.

Navas, C. A.; Antoniazzi, M. M.; Carvalho, J. E.; Chaui-Berlink, J. G.; James, R. S.; Jared, C.; Kohlsdorf, T.; Pai-Silva, M. D. \& Wilson, R. S. 2004. Morphological and physiological specialization for digging in amphisbaenians, an ancient lineage of fossorial vertebrates. The Journal of Experimental Biology 207:2433-2441.

Navega-Gonçalves, M. E. 2009. Anatomia visceral comparada de seis espécies de Amphisbaenidae (Squamata: Amphisbaenia). Zoologia 26:511-526. 
R Core TeAm. 2013. R: A language and environment for statistical computing.. Vienna, R: Foundation for Statistical Computing. Available in: <http://www.R-project.org/>. Accessed on February 2013.

Roberto, I. J.; Brito, L. B. M. \& Ávila, R. W. 2014. A new six-pored Amphisbaena (Squamata: Amphisbaenidae) from the coastal zone of northeast Brazil. Zootaxa 3753:167-176.

Shine, R. 1994. Sexual size dimorphism in snakes revisited. Copeia 2:326-346.

Silva-Soares, T.; Ferreira, R. B.; Salles, R. O. L. \& Rocha, C. F. D. 2011. Continental, insular and coastal marine reptiles from the municipality of Vitória, state of Espírito Santo, southeastern Brazil. Check list 7:290-298.

Strüssmann, C. \& Motт, T. 2009. Sympatric amphisbaenids from Manso Dam region, Mato Grosso State, Western Brazil, with the description of a new two-pored species of Amphisbaena (Squamata, Amphisbaenidae). Studies on Neotropical Fauna and Environment 44:37-46.
Townsend, T. M.; Larson, A.; Louis, E. \& Macey, J. R. 2004. Molecular phylogenetics of Squamata: The position of snakes, amphisbaenians, and dibamids, and the root of the squamate tree. Systematic Biology 53:735-757.

Uetz, P. 2014. The reptile database. Available at $<$ http://www.reptiledatabase.org > . Accessed on: 20 July 2014.

VAnzolini, P. E. 2002. An aid to the identification of the South American species of Amphisbaena (Squamata, Amphisbaenidae). Papéis Avulsos de Zoologia 42:351-362.

VEGA, L. E. 2001. Reproductive and feeding ecology of the amphisbaenian Anops kingii in east-central Argentina. Amphibia-Reptilia 22:447454.

Vidal, N.; Azvolinsky, A.; Cruaud, C. \& Hedges, S. H. 2008. Origin of tropical American burrowing reptiles by transatlantic rafting. Biology Letters 4:115-118.

Webb, J. K.; Shine, R.; Branch, W. R. \& Harlow, P. S. 2000. Life underground: Food habits and reproductive biology of two amphisbaenian species from southern Africa. Journal of Herpetology 34:510-516.

APPENDIX

Specimens of Amphisbaena nigricauda Gans, 1966 examined [F, female $(\mathrm{n}=80) ;$ M, male $(\mathrm{n}=62)$; N/D, sex not determinate, mutilated specimens ( $\mathrm{n}=36)$; SVL, snout-vent length; TL, tail length].

\begin{tabular}{|c|c|c|c|c|c|c|c|c|c|}
\hline \multirow[b]{2}{*}{$\begin{array}{c}\text { Institution } \\
\text { number }\end{array}$} & \multicolumn{2}{|c|}{ Length (mm) } & \multicolumn{3}{|c|}{ Annuli } & \multicolumn{2}{|c|}{ Segments } & \multirow[b]{2}{*}{$\begin{array}{l}\text { Number } \\
\text { of pores }\end{array}$} & \multirow[b]{2}{*}{ sex } \\
\hline & $\begin{array}{c}\text { Body } \\
\text { (SVL) }\end{array}$ & Tail (TL) & Body & Intercalated & Tail & Dorsal & Ventral & & \\
\hline UFMT 9141 & 105 & 4 & 215 & 5 & 8 & 15 & 11 & - & $\mathrm{N} / \mathrm{D}$ \\
\hline UFMT 9142 & 130 & 7 & 218 & 7 & 8 & 15 & 10 & 0 & $\mathrm{~F}$ \\
\hline UFMT 9143 & 111 & 5 & 211 & 9 & 8 & 14 & 9 & 0 & F \\
\hline UFMT 9144 & - & 15 & - & - & 21 & 15 & 10 & 0 & $\mathrm{~F}$ \\
\hline UFMT 9145 & 123 & 16 & 212 & 10 & 20 & 14 & 9 & 0 & $\mathrm{~F}$ \\
\hline UFMT 9146 & 85 & 10 & 204 & 13 & 22 & 13 & 10 & 0 & $\mathrm{~F}$ \\
\hline UFMT 9147 & 100 & 4 & 216 & 2 & 8 & 14 & 9 & - & N/D \\
\hline UFMT 9148 & 90 & 12 & 215 & 3 & 21 & 15 & 10 & 0 & $\mathrm{~F}$ \\
\hline UFMT 9150 & 0 & 0 & . & . & 20 & 14 & 9 & 4 & M \\
\hline UFMT 9151 & 125 & 5 & 218 & 1 & 8 & 15 & 10 & 4 & M \\
\hline UFMT 9152 & 132 & 15 & 220 & 1 & 21 & 15 & 11 & 4 & M \\
\hline UFMT 9153 & - & - & - & - & - & 15 & 11 & - & $\mathrm{N} / \mathrm{D}$ \\
\hline UFMT 9154 & - & - & - & - & - & - & - & - & N/D \\
\hline UFMT 9155 & - & - & - & - & - & - & - & - & $\mathrm{N} / \mathrm{D}$ \\
\hline UFMT 9156 & 127 & 15 & 209 & 1 & 21 & 15 & 9 & 0 & $\mathrm{~F}$ \\
\hline UFMT 9157 & 133 & 16 & 208 & 3 & 21 & 15 & 11 & 0 & F \\
\hline UFMT 9158 & 125 & 7 & 208 & 1 & 8 & 15 & 11 & 0 & F \\
\hline UFMT 9159 & 132 & 15 & 210 & 3 & 22 & 15 & 10 & 0 & $\mathrm{~F}$ \\
\hline UFMT 9160 & 138 & 17 & 218 & 0 & 19 & 15 & 11 & 0 & F \\
\hline UFMT 9161 & 110 & 13 & 217 & 0 & 21 & 14 & 9 & 0 & $\mathrm{~F}$ \\
\hline UFMT 9162 & 128 & 15 & 209 & 2 & 22 & 15 & 10 & 0 & F \\
\hline UFMT 9163 & 113 & 14 & 212 & 0 & 22 & 15 & 11 & 0 & $\mathrm{~F}$ \\
\hline UFMT 9164 & 90 & 4 & 210 & 1 & 8 & 15 & 10 & 0 & $\mathrm{~F}$ \\
\hline UFMT 9166 & 128 & 17 & 215 & 1 & 21 & 15 & 9 & 4 & M \\
\hline UFMT 9167 & 135 & 16 & 208 & 4 & 21 & 15 & 9 & 4 & M \\
\hline UFMT 9168 & 145 & 6 & 215 & 6 & 8 & 15 & 10 & 4 & M \\
\hline UFMT 9169 & 109 & 13 & 208 & 2 & 22 & 15 & 9 & 4 & M \\
\hline UFMT 9170 & 125 & 15 & 213 & 2 & 22 & 16 & 10 & 4 & M \\
\hline UFMT 9171 & 130 & 15 & 208 & 1 & 21 & 15 & 10 & 4 & $\mathrm{M}$ \\
\hline MBML 3022 & 137 & 6 & 205 & 10 & 8 & 14 & 11 & - & $\mathrm{N} / \mathrm{D}$ \\
\hline MBML 3023 & 135 & 16 & 211 & 8 & 21 & 15 & 10 & 0 & $\mathrm{~F}$ \\
\hline MBML 3024 & 124 & 15 & 212 & 1 & 22 & 15 & 10 & 4 & M \\
\hline MBML 3025 & 119 & 13 & 207 & 2 & 22 & 15 & 10 & 0 & $\mathrm{~F}$ \\
\hline MBML 3026 & 135 & 14 & 210 & 0 & 20 & 15 & 10 & 0 & F \\
\hline MBML 3027 & 118 & 5 & 206 & 4 & 7 & 14 & 10 & 0 & $\mathrm{~F}$ \\
\hline MBML 3028 & 74 & 8 & 212 & 2 & 21 & - & - & - & $\mathrm{N} / \mathrm{D}$ \\
\hline
\end{tabular}


APPENDIX (cont.)

\begin{tabular}{|c|c|c|c|c|c|c|c|c|c|}
\hline MBML 3029 & 121 & 16 & 206 & 10 & 22 & 14 & 9 & 4 & $\mathrm{M}$ \\
\hline MBML 3030 & 131 & 5 & 210 & 0 & 8 & 15 & 11 & 0 & $\mathrm{~N} / \mathrm{D}$ \\
\hline MBML 3031 & 126 & 15 & 211 & 0 & 21 & 15 & 9 & 4 & $\mathrm{M}$ \\
\hline MBML 3032 & 146 & 5 & 208 & 1 & 7 & 15 & 10 & 0 & $\mathrm{~F}$ \\
\hline MBML 3033 & 145 & 27 & 205 & 3 & 22 & 15 & 11 & 4 & M \\
\hline MBML 3034 & 137 & 5 & 217 & 1 & 8 & 15 & 11 & 0 & $\mathrm{~F}$ \\
\hline MBML 3035 & 135 & 7 & 217 & 0 & 8 & 15 & 11 & 4 & M \\
\hline MBML 3036 & 134 & 6 & 212 & 1 & 7 & 15 & 11 & 0 & $\mathrm{~F}$ \\
\hline MBML 3037 & 137 & 6 & 216 & 3 & 8 & 15 & 10 & 0 & F \\
\hline MBML 3038 & 136 & 7 & 211 & 3 & 8 & 16 & 11 & 4 & M \\
\hline MBML 3039 & 144 & 17 & 211 & 0 & 22 & 15 & 11 & 0 & $\mathrm{~F}$ \\
\hline MBML 3040 & 127 & 5 & 205 & 4 & 8 & 15 & 9 & 0 & F \\
\hline MBML 3041 & 116 & 3 & 214 & 6 & 8 & 15 & 11 & 0 & F \\
\hline MBML 3042 & 132 & 5 & 200 & 6 & 8 & 15 & 10 & 0 & F \\
\hline MBML 3043 & 142 & 17 & 219 & 4 & 22 & 15 & 11 & 0 & F \\
\hline MBML 3044 & 122 & 5 & 192 & 19 & 7 & 15 & 11 & 0 & F \\
\hline MBML 3045 & 150 & 17 & 213 & 0 & 21 & 15 & 11 & 0 & $\mathrm{~F}$ \\
\hline MBML 3046 & 135 & 16 & 220 & 2 & 21 & 15 & 10 & 0 & $\mathrm{~F}$ \\
\hline MBML 3047 & 142 & 16 & 208 & 2 & 21 & 15 & 11 & 4 & M \\
\hline MBML 3048 & 134 & 6 & 206 & 3 & 8 & 15 & 11 & 0 & $\mathrm{~F}$ \\
\hline MBML 3049 & 138 & 7 & 212 & 2 & 8 & 13 & 9 & 4 & M \\
\hline MBML 3050 & 115 & 15 & 218 & 5 & 22 & 15 & 11 & 0 & $\mathrm{~F}$ \\
\hline MBML 3051 & 92 & 3 & 205 & 1 & 8 & 15 & 9 & 0 & $\mathrm{~F}$ \\
\hline MBML 3052 & 140 & 5 & 202 & 3 & 8 & 15 & 9 & 4 & M \\
\hline MBML 3053 & 112 & 5 & 209 & 3 & 8 & 14 & 11 & 4 & M \\
\hline MBML 3054 & 121 & 5 & 213 & 1 & 8 & 15 & 9 & 4 & M \\
\hline MBML 3055 & 152 & 5 & 220 & 0 & 8 & 15 & 11 & 4 & M \\
\hline MBML 3056 & 149 & 6 & 218 & 1 & 8 & 15 & 11 & 4 & $\mathrm{M}$ \\
\hline MBML 3057 & 118 & 11 & 216 & 6 & 22 & 15 & 11 & - & N/D \\
\hline MBML 3058 & 132 & 16 & 210 & 2 & 21 & 15 & 11 & 4 & $\mathrm{M}$ \\
\hline MBML 3059 & 124 & 6 & 209 & 1 & 8 & 15 & 11 & 4 & M \\
\hline MBML 3060 & 127 & 15 & 208 & 5 & 21 & 15 & 10 & 0 & $\mathrm{~F}$ \\
\hline MBML 3061 & - & - & - & - & - & - & - & - & $\mathrm{N} / \mathrm{D}$ \\
\hline MBML 3062 & - & 15 & - & - & 22 & - & - & 4 & M \\
\hline MBML 3063 & - & 15 & 210 & 2 & 21 & 13 & 9 & 4 & $\mathrm{M}$ \\
\hline MBML 3064 & - & - & - & - & - & - & - & - & $\mathrm{N} / \mathrm{D}$ \\
\hline MBML 3065 & - & - & - & - & - & - & - & - & $\mathrm{N} / \mathrm{D}$ \\
\hline MBML 3066 & - & 14 & - & - & 21 & - & - & 4 & M \\
\hline MBML 3067 & - & - & - & - & - & - & - & - & $\mathrm{N} / \mathrm{D}$ \\
\hline MBML 3068 & - & - & - & - & - & - & - & - & $\mathrm{N} / \mathrm{D}$ \\
\hline MBML 3069 & - & 4 & - & - & 8 & - & - & - & $\mathrm{N} / \mathrm{D}$ \\
\hline MBML 3070 & - & - & - & - & - & - & - & - & $\mathrm{N} / \mathrm{D}$ \\
\hline MBML 3071 & - & - & - & - & - & - & - & - & $\mathrm{N} / \mathrm{D}$ \\
\hline MBML 3072 & - & - & - & - & - & - & - & - & $\mathrm{N} / \mathrm{D}$ \\
\hline MBML 3073 & - & - & - & - & - & - & - & - & $\mathrm{N} / \mathrm{D}$ \\
\hline MBML 3074 & - & 17 & - & - & 22 & - & - & 4 & $\mathrm{M}$ \\
\hline MBML 3075 & 141 & 5 & 211 & - & 8 & 15 & 11 & 0 & $\mathrm{~F}$ \\
\hline MBML 3076 & 135 & 15 & 204 & 13 & 20 & 15 & 10 & 0 & $\mathrm{~F}$ \\
\hline MBML 3077 & 145 & 18 & 218 & 2 & 23 & 15 & 11 & 4 & M \\
\hline MBML 3078 & 134 & 6 & 212 & 8 & 8 & 15 & 10 & 4 & M \\
\hline MBML 3079 & 127 & 5 & 216 & 0 & 7 & 15 & 11 & 0 & $\mathrm{~F}$ \\
\hline MBML 3080 & 140 & 7 & 216 & 1 & 9 & 15 & 11 & 0 & $\mathrm{~F}$ \\
\hline MBML 3081 & 130 & 5 & 214 & 4 & 8 & 15 & 11 & 0 & $\mathrm{~F}$ \\
\hline MBML 3082 & 131 & 14 & 206 & 15 & 20 & 15 & 11 & 0 & M \\
\hline MBML 3083 & 135 & 15 & 220 & 2 & 21 & 15 & 11 & 0 & $\mathrm{~F}$ \\
\hline MBML 3084 & 112 & 4 & 217 & 0 & 7 & 15 & 11 & 0 & $\mathrm{~F}$ \\
\hline MBML 3085 & 128 & 5 & 215 & 1 & 8 & 15 & 11 & 0 & $\mathrm{~F}$ \\
\hline MBML 3086 & 139 & 6 & 216 & 0 & 8 & 15 & 11 & 4 & M \\
\hline MBML 3087 & 147 & 5 & 217 & 3 & 7 & 15 & 11 & 0 & $\mathrm{~F}$ \\
\hline
\end{tabular}




\begin{tabular}{|c|c|c|c|c|c|c|c|c|c|}
\hline MBML 3088 & 126 & 5 & 201 & 16 & 8 & 15 & 11 & 0 & F \\
\hline MBML 3089 & 133 & 5 & 218 & 0 & 8 & 15 & 11 & 0 & F \\
\hline MBML 3090 & 118 & 4 & 216 & 6 & 8 & 15 & 11 & 0 & F \\
\hline MBML 3091 & 142 & 8 & 215 & 1 & 9 & 15 & 11 & 4 & M \\
\hline MBML 3092 & 146 & 18 & 212 & 0 & 23 & 15 & 11 & 4 & M \\
\hline MBML 3093 & 137 & 15 & 212 & 7 & 21 & 15 & 11 & 0 & $\mathrm{~F}$ \\
\hline MBML 3094 & 132 & 17 & 207 & 3 & 22 & 15 & 11 & 0 & F \\
\hline MBML 3095 & 131 & 5 & 211 & 1 & 8 & 15 & 11 & 0 & $\mathrm{~F}$ \\
\hline MBML 3096 & 135 & 17 & 216 & 1 & 22 & 15 & 11 & 5 & M \\
\hline MBML 3097 & 135 & 6 & 209 & 7 & 8 & 15 & 11 & 0 & $\mathrm{~F}$ \\
\hline MBML 3098 & 137 & 7 & 220 & 0 & 8 & 15 & 9 & 4 & M \\
\hline MBML 3099 & 138 & 16 & 219 & 2 & 22 & 15 & 11 & 4 & M \\
\hline MBML 3100 & 127 & 15 & 215 & 1 & 22 & 15 & 9 & 4 & M \\
\hline MBML 3101 & 114 & 7 & 216 & 5 & 22 & 15 & 11 & 0 & $\mathrm{~F}$ \\
\hline MBML 3102 & 130 & 5 & 214 & 4 & 9 & 15 & 11 & 0 & F \\
\hline MBML 3103 & 125 & 5 & 222 & 0 & 8 & - & - & 0 & $\mathrm{~F}$ \\
\hline MBML 3104 & 111 & 13 & 213 & 2 & 21 & 15 & 11 & 0 & $\mathrm{~F}$ \\
\hline MBML 3105 & 136 & 16 & 217 & 3 & 21 & 15 & 11 & 0 & $\mathrm{~F}$ \\
\hline MBML 3106 & 130 & 6 & 216 & 0 & 8 & 15 & 11 & 4 & M \\
\hline MBML 3107 & 131 & 15 & 216 & 3 & 21 & 15 & 11 & 4 & M \\
\hline MBML 3108 & 123 & 5 & 216 & 0 & 8 & 15 & 11 & 4 & M \\
\hline MBML 3109 & 136 & 6 & 220 & 9 & 8 & 14 & 11 & 4 & M \\
\hline MBML 3110 & 137 & 17 & 207 & 1 & 22 & 15 & 11 & 4 & M \\
\hline MBML 3111 & 137 & 17 & 219 & 1 & 23 & 15 & 11 & 4 & M \\
\hline MBML 3112 & 133 & 7 & 215 & 1 & 8 & 15 & 11 & 4 & M \\
\hline MBML 3113 & 131 & 15 & 218 & 1 & 22 & 15 & 11 & 0 & $\mathrm{~F}$ \\
\hline MBML 3114 & 121 & 15 & 213 & 4 & 21 & - & - & 4 & M \\
\hline MBML 3115 & 126 & 16 & 216 & 2 & 22 & 15 & 10 & 4 & M \\
\hline MBML 3116 & 135 & 5 & 217 & 1 & 8 & 14 & 11 & 0 & $\mathrm{~F}$ \\
\hline MBML 3117 & 126 & 6 & 210 & 3 & 7 & 15 & 10 & 4 & M \\
\hline MBML 3118 & 134 & 6 & 212 & 2 & 8 & 15 & 11 & 4 & M \\
\hline MBML 3119 & 136 & 17 & 217 & 1 & 21 & 15 & 11 & 0 & $\mathrm{~F}$ \\
\hline MBML 3120 & 107 & 12 & 213 & 3 & 22 & 14 & 10 & 0 & $\mathrm{~F}$ \\
\hline MBML 3121 & 90 & 4 & 221 & 1 & 8 & 15 & 11 & 0 & $\mathrm{~F}$ \\
\hline MBML 3122 & 116 & 5 & 218 & 8 & 8 & 15 & 11 & 4 & M \\
\hline MBML 3123 & 130 & 15 & 214 & 3 & 22 & 15 & 11 & 4 & M \\
\hline MBML 3124 & 100 & 4 & 213 & 2 & 8 & - & - & 0 & $\mathrm{~F}$ \\
\hline MBML 3125 & 126 & 5 & 205 & 5 & 8 & 15 & 11 & 4 & M \\
\hline MBML 3126 & 104 & 4 & 214 & 5 & 7 & 15 & 11 & 0 & $\mathrm{~F}$ \\
\hline MBML 3127 & 90 & 11 & 215 & 3 & 22 & 15 & 11 & 0 & $\mathrm{~F}$ \\
\hline MBML 3128 & 140 & 17 & 215 & 2 & 22 & 15 & 11 & 4 & M \\
\hline MBML 3129 & 126 & 6 & 212 & 0 & 8 & 15 & 11 & 0 & $\mathrm{~F}$ \\
\hline MBML 3130 & 131 & 4 & 215 & 7 & 7 & 15 & 11 & 0 & $\mathrm{~F}$ \\
\hline MBML 3131 & 121 & 14 & 208 & 11 & 21 & 14 & 11 & 4 & $\mathrm{M}$ \\
\hline MBML 3132 & 79 & 9 & 212 & 2 & 21 & 14 & 11 & - & $\mathrm{N} / \mathrm{D}$ \\
\hline MBML 3133 & 106 & 11 & 217 & 3 & 22 & 15 & 11 & 0 & $\mathrm{~F}$ \\
\hline MBML 3134 & 121 & 5 & 218 & 1 & 7 & 15 & 10 & 0 & $\mathrm{~F}$ \\
\hline MBML 3135 & 107 & 13 & 209 & 19 & 21 & 15 & 11 & 0 & F \\
\hline MBML 3136 & 90 & 3 & 226 & 1 & 7 & 14 & 10 & 0 & $\mathrm{~F}$ \\
\hline MBML 3137 & 126 & 14 & 219 & 0 & 20 & 15 & 10 & 4 & M \\
\hline MBML 3138 & 95 & 12 & 214 & 4 & 22 & 15 & 11 & 0 & $\mathrm{~F}$ \\
\hline MBML 3139 & 125 & 5 & 212 & 5 & 8 & 15 & 11 & 0 & $\mathrm{~F}$ \\
\hline MBML 3140 & 136 & 18 & 216 & 1 & 22 & 15 & 11 & 4 & M \\
\hline MBML 3141 & 132 & 16 & 212 & 1 & 22 & 15 & 9 & 0 & $\mathrm{~F}$ \\
\hline MBML 3142 & - & 16 & - & - & 22 & - & - & 0 & $\mathrm{~F}$ \\
\hline MBML 3143 & - & - & - & - & - & - & - & - & $\mathrm{N} / \mathrm{D}$ \\
\hline MBML 3144 & - & - & - & - & - & - & - & - & $\mathrm{N} / \mathrm{D}$ \\
\hline MBML 3145 & - & 15 & - & - & 22 & - & - & 0 & $\mathrm{~F}$ \\
\hline MBML 3146 & - & 6 & - & - & 9 & - & - & 4 & $\mathrm{M}$ \\
\hline
\end{tabular}




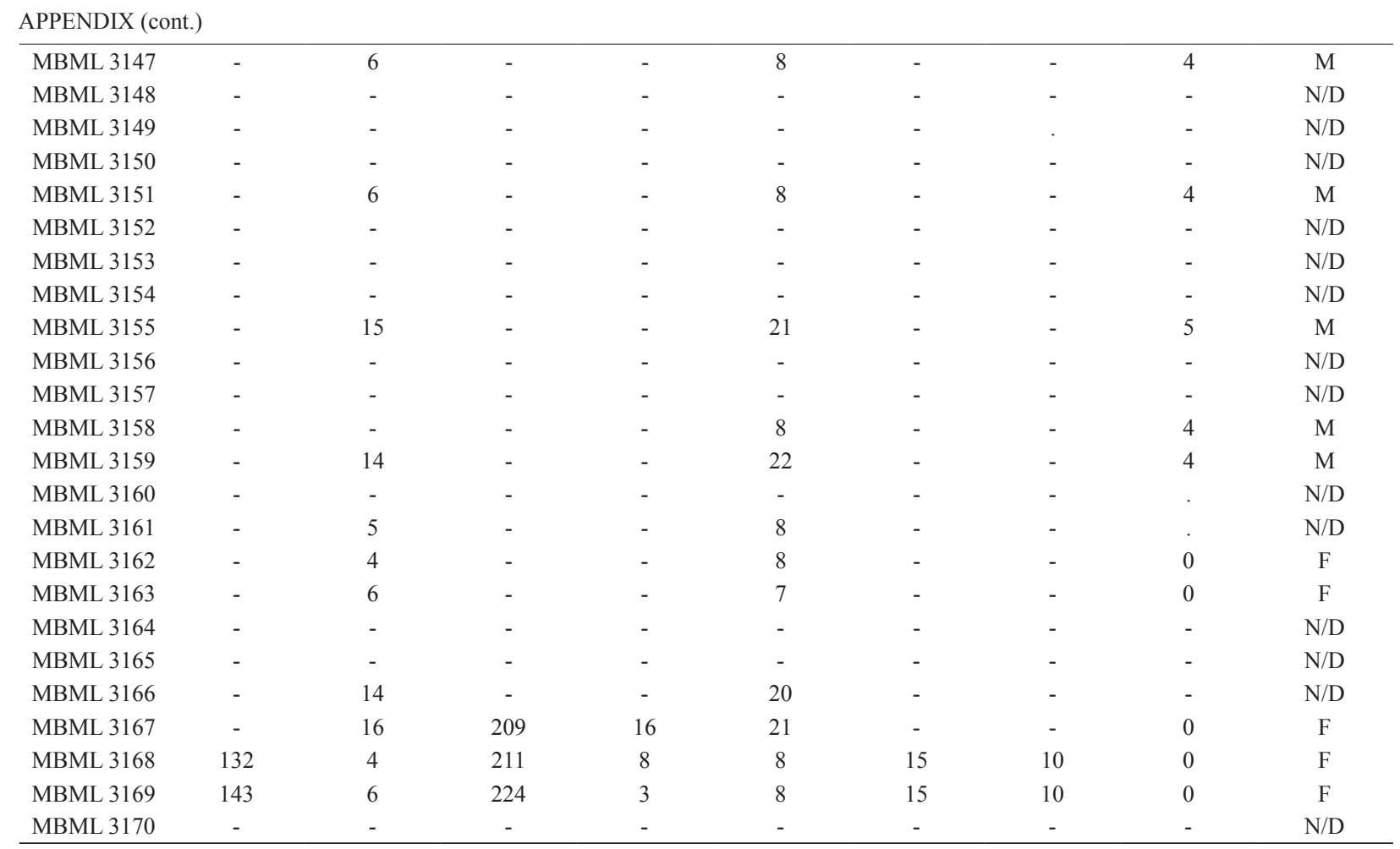

